\title{
THE ROLE AND SIGNIFICANCE OF GASTRONOMIC TOURISM FOR RURAL AREAS OF THE MUNICIPALITY OF APATIN
}

Olgica Zečević Stanojevićl, Aleksandra Vujko², Leposava Zečević ${ }^{3}$

*Corresponding authorE-mail: aleksandravujko@yahoo.com

A R T I C L E I N F O
Original Article
Received: 15 October 2021
Accepted: 29 November 2021
doi:10.5937/ekoPolj2104043Z
UDC 338.48-6:641/642
(497.11Apatin)

Keywords:

tourism, gastronomy, promotion, the development of rural areas

JEL: Q15, R11

\section{A B S T R A C T}

The paper starts with the initial hypothesis that traditional, i.e. local food served in local restaurants (chardas) is the basis for the development of rural areas. By setting certain sub-hypotheses, we highlight the primary purpose of the paper, and thus we show that traditional food has the "strength" to change and improve rural areas. We based the research on a changed questionnaire previously used for research in the Black Sea resorts of Romania. The questionnaire comprises of 9 attributes, and we asked respondents to rank certain attributes on a three-point scale. The research was conducted among visitors who came from eight countries, including Serbia, to get the most relevant data through statistical processing, which will serve to assess the current, but also to predict the future state and development of gastronomic tourism.

(C) 2021 EA. All rights reserved.

\section{Introduction}

Since food and beverage are recognized as important factors in attracting tourists, we consider gastronomic tourism to be the backbone of the development of rural areas. (Hall, Mitchell, 2001; Hjalager, Richards, 2002; Charters, Pettigrew, 2005; Wolf, 2006; Petrović et al., 2017; Vuković et al., 2019; Vujko et al., 2020). Food has the "power" to attract tourists contributing to the transformation of rural areas into tourist destinations. It is well

1 Olgica Zečević Stanojević, Full Professor, European University, Faculty of European Business and Marketing, Vojvode Dobrnjca 15, Belgrade 11000, Serbia, Phone: +38163233599; E-mail: olgicazs@gmail.com

2 Aleksandra Vujko, Ass. Professor, University of Business Studies, Faculty of Tourism and Hotel Management (Jovana Dučića 23a, Banja Luka 78000, Republic of Srpska); European University, Faculty of European Business and Marketing, Vojvode Dobrnjca 15, Belgrade 11000, Serbia, Phone: +381 64914 2645, E-mail: aleksandravujko@yahoo.com, ORCID ID (https://orcid.org/0000-0001-8684-4228)

3 Leposava Zečević, Ph.D., Full Professor, European University, Faculty of European Business and Marketing, Vojvode Dobrnjca 15, Belgrade 11000, Serbia, Phone: +38163233599; E-mail: bekaz70@gmail.com 
known that tourists travel to different parts of the world just to try something new and to experience through "taste" new destinations in this specific way. (Kivela, Crotts, 2006).

The municipality of Apatin is in the southwest part of the province of Vojvodina (West Bačka District), on the left side of the Danube. It occupies the space of $333 \mathrm{~km}^{2}$, with approximately 35,000 inhabitants in one urban and four rural areas (Prigrevica, Kupusina, Svilojevo, and Sonta), (Radujko, 2008; Bošković, 2013; Tadić, 2018). Regional route R 101 connects Apatin and Sombor $(16 \mathrm{~km})$ and the borders with the Republic of Croatia near Bogojevo $(35 \mathrm{~km})$. Apatin is $100 \mathrm{~km}$ away from Novi Sad, via Odžak, and $120 \mathrm{~km}$ via Vrbas Two geomorphologic environments are represented in the municipality's relief: the alluvial plain of the Danube and the light terrace, with an average altitude of 85 m (Radujko, 2008; Bošković, 2013; Tadić, 2018).

The tourist attractions in the region are the very rich fishing waters on the Danube and its branches, as well as famous hunting places, habitats of the famous Danube deer and other game animals. Apatin has long been known as a fishing center. The floodplain of the special nature reserve "Gornje Podunavlje" is a natural hatchery for about 50 species of freshwater fish, among which the most important species are: carp, pike, perch, catfish, etc. (Rudić-Vranić, 1960; Ćopić, 2016). Also, the Apatin fishing culinary tradition is well known, as well as the manifestation "Apatin Fishermen's Evenings".

The paper tries to show that food and gastronomic tourism are a powerful magnet for attracting tourists, and a mighty instrument with the help of which the invested money will return many times. Such investment directly affects the development of rural areas, which is the starting hypothesis of the paper. The primary aim of the paper is to prove that traditional food has the "strength" to change and improve rural areas, and gastronomic tourism represents the backbone of development. What we conclude is that certain items influence the overall impression which gastronomy makes on tourists. Thus, new aims of the paper emerged, i.e. to investigate whether tourists are satisfied with their stay at the destination and whether this stay fulfilled their expectations; also, to check the quality of the food that was served, as well as to check the quality of the service in chardas.

\section{The research methodology}

The survey was conducted among the guests of three well known chardas on the territory of the municipality of Apatin, "Zlatna Kruna", "Harčaš" charda, and "Kupusinska" charda from May until September 2018, and included 234 participants of different gender, age, and educational background.

The quantitative-qualitative method, which is one of the most used methods, is used in this paper because it allows great freedom in research and evaluation, and is based on the following indicators: accessibility of resources, tourist equipment, environment, resource specificity, resource significance, and artistic value. For this paper, we did the valorization of gastronomic tourism on the Danube chardas of the municipality of Apatin: Charda"Zlatna kruna" (Golden Crown), "Harčaš” charda, and "Kupusinska" 
charda. Valorization was performed by Dragan Ignjatov and Đurđina Knezević. Locating the destination or zoning, was done by drawing and connecting points on the map of Apatin. A tour of the city during the visit to the Apatin chardas is shown.

We based this study on a changed questionnaire that was primarily conducted in the Black Sea resorts of Romania in August 1997 and implemented by Nield, Kozak \& LeGrys (2000). According to Nield, Kozak \& LeGrys (2000), the participants were asked to rate nine attributes (Value for money, Food quality, Number of dishes, Standard of food service, Variety of dishes, Food presentation, Overall traditional meal experience, Speed of service, Attractiveness of surroundings) of food service (on a three-point scale).

A three-point scale, although unusual, was employed to give unequivocal answers regarding tourists' likes and dislikes. Within the three-point scale, the item 'like' refers to the respondents' favorite opinions about the food and beverage and the item 'dislike' refers to their unfavorable opinions. The item 'neither' was inserted for those who neither liked nor disliked an item. By applying the appropriate research instruments, the survey included variables that primarily concerned the participants' opinions of the linkage between traditional food and loyalty. The variables reflect the opinion of the participants about the food, food service, the attractiveness of surroundings, and loyalty.

The collected data was analyzed by employing the Statistical Package for the Social Sciences (SPSS) program. This data was analyzed by appropriate statistical methods which were descriptive and comparative, enabling the explication of the research results and the performing certain conclusions.

One form of the analysis of the data was the chi-square test (Pearson Chi-Square Test). It was used to determine whether a received (observed) frequency (the responses of participants compared to the origin country) deviated from the frequencies that were expected. This test aimed to check if there was a connection between these groups of participants and the probability of connection. Practice is to always start from the premise that there are certain values of the difference in responses. To detect differences in the responses measured based on statistically significant differences in the distribution of the dependent variable to an independent one, statistically significant differences are taken for those having $\mathrm{p}<0,05$.

In this paper, we started from the main hypothesis $\mathrm{H}$ : Traditional food is the reason for the development of the rural areas. Certain lower-level hypotheses are set under the main one: h1-staying at the destination fulfilled the expectations (Table 1); h2the traditional food is presented in the right manner (Table 11); h3-the environment that surrounds the Apatin chardas (national restaurants) is attractive and improves the overall impression (Table 13, 17); h4-the food and service in the restaurants represent the product which becomes the basis of tourist loyalty (Table 3, 5, 7, 9, 15) 


\section{Results and discussion}

According to Günther (2021), money can strongly 'affect people's reactions. It is well established that Value for money, Food quality, Number of dishes, Standard of food service, Variety of dishes, Food presentation, Overall traditional meal experience, Speed of service, and Attractiveness of surroundings affect customer's willingness to pay a food price. That feeling is directly proportional to the need of enjoying food, and also with "the wish to be seen" at a certain destination (Mora et al., 2021).

Table 1. Opinion of the participants

\begin{tabular}{|c|c|c|c|c|c|c|}
\hline & \multicolumn{3}{|c|}{ Value for money } & \multirow{2}{*}{ Total } \\
\hline & & & Like & Dislike & Neither & \\
\hline \multirow{16}{*}{ Country of origin } & \multirow{2}{*}{ Serbia } & Count & 37 & 1 & 1 & 39 \\
\hline & & $\%$ of Total & $12,5 \%$ &, $3 \%$ &, $3 \%$ & $13,2 \%$ \\
\hline & \multirow{2}{*}{$\mathrm{B} \& \mathrm{H}$} & Count & 56 & 3 & 2 & 61 \\
\hline & & $\%$ of Total & $19,0 \%$ & $1,0 \%$ &, $7 \%$ & $20,7 \%$ \\
\hline & \multirow{2}{*}{ Croatia } & Count & 22 & 1 & 1 & 24 \\
\hline & & $\%$ of Total & $7,5 \%$ &, $3 \%$ &, $3 \%$ & $8,1 \%$ \\
\hline & \multirow{2}{*}{ Macedonia } & Count & 7 & 0 & 0 & 7 \\
\hline & & $\%$ of Total & $2,4 \%$ &, $0 \%$ &, $0 \%$ & $2,4 \%$ \\
\hline & \multirow{2}{*}{ Montenegro } & Count & 34 & 2 & 1 & 37 \\
\hline & & $\%$ of Total & $11,5 \%$ &, $7 \%$ &, $3 \%$ & $12,5 \%$ \\
\hline & \multirow{2}{*}{ Slovenia } & Count & 74 & 3 & 2 & 79 \\
\hline & & $\%$ of Total & $25,1 \%$ & $1,0 \%$ &, $7 \%$ & $26,8 \%$ \\
\hline & \multirow{2}{*}{ Greece } & Count & 22 & 1 & 2 & 25 \\
\hline & & $\%$ of Total & $7,5 \%$ &, $3 \%$ &, $7 \%$ & $8,5 \%$ \\
\hline & \multirow{2}{*}{ Hungary } & Count & 18 & 3 & 2 & 23 \\
\hline & & $\%$ of Total & $6,1 \%$ & $1,0 \%$ &, $7 \%$ & $7,8 \%$ \\
\hline \multirow{2}{*}{\multicolumn{2}{|c|}{ Total }} & Count & 270 & 14 & 11 & 295 \\
\hline & & $\%$ of Total & $91,5 \%$ & $4,7 \%$ & $3,7 \%$ & $100,0 \%$ \\
\hline
\end{tabular}

Source: Own calculations

By examining table 1, we see that most participants claimed they received what they expected for the money, which proves the hypothesis $\mathrm{h} 1$ - staying at the destination fulfilled the expectations. In Pearson Chi-Square Test, comparisons are made depending on the country from which tourists come. Referring to the data from table 2, we can conclude that there is no statistically significant difference in participants' responses depending on the country they come from, since $p=8.515$. Therefore, wherever participants come from, they all agree that they got the highest value for the money spent, and all of them were satisfied.

Table 2 Pearson Chi-Square Test

\begin{tabular}{|l|l|l|l|}
\hline Attachment 1. & Value & df & Statistical significance (p) \\
\hline Pearson Chi-Square Test Male & 8.515 & 14 & 0.861 \\
\hline
\end{tabular}

Source: Own calculations 
For Mak et al. (2012b), quality of food, number of dishes, and quality of service significantly impact tourist satisfaction and thus affect the perception of gastronomic tourism and rural areas. In this sense, food positively affects satisfaction and intentions to return to a destination. Apart from this, food quality in relation to quality service directly influences the positive aspects of rural areas' development. When one talks about food quality, it is primarily about the quality of the ingredients they made a certain dish of. Organic products are ecologically grown and healthy habits are valued most.

Table 3. Opinion of the participants

\begin{tabular}{|c|c|c|c|c|c|}
\hline & \multicolumn{2}{|c|}{ Food quality } & \multirow{2}{*}{ Total } \\
\hline & & & Like & Neither & \\
\hline \multirow{16}{*}{ Country of origin } & \multirow{2}{*}{ Serbia } & Count & 38 & 1 & 39 \\
\hline & & $\%$ of Total & $12,9 \%$ &, $3 \%$ & $13,2 \%$ \\
\hline & \multirow{2}{*}{$\mathrm{B} \& \mathrm{H}$} & Count & 61 & 0 & 61 \\
\hline & & $\%$ of Total & $20,7 \%$ &, $0 \%$ & $20,7 \%$ \\
\hline & \multirow{2}{*}{ Croatia } & Count & 24 & 0 & 24 \\
\hline & & $\%$ of Total & $8,1 \%$ &, $0 \%$ & $8,1 \%$ \\
\hline & \multirow{2}{*}{ Macedonia } & Count & 7 & 0 & 7 \\
\hline & & $\%$ of Total & $2,4 \%$ &, $0 \%$ & $2,4 \%$ \\
\hline & \multirow{2}{*}{ Montenegro } & Count & 37 & 0 & 37 \\
\hline & & $\%$ of Total & $12,5 \%$ &, $0 \%$ & $12,5 \%$ \\
\hline & \multirow{2}{*}{ Slovenia } & Count & 74 & 5 & 79 \\
\hline & & $\%$ of Total & $25,1 \%$ & $1,7 \%$ & $26,8 \%$ \\
\hline & \multirow{2}{*}{ Greece } & Count & 25 & 0 & 25 \\
\hline & & $\%$ of Total & $8,5 \%$ &, $0 \%$ & $8,5 \%$ \\
\hline & \multirow{2}{*}{ Hungary } & Count & 23 & 0 & 23 \\
\hline & & $\%$ of Total & $7,8 \%$ &, $0 \%$ & $7,8 \%$ \\
\hline \multirow{2}{*}{\multicolumn{2}{|c|}{ Total }} & Count & 289 & 6 & 295 \\
\hline & & $\%$ of Total & $98,0 \%$ & $2,0 \%$ & $100,0 \%$ \\
\hline
\end{tabular}

Source: Own calculations

Pearson Chi-Square Test ( $\mathrm{p}=11.044$ in the case of table 4, also showed that there was no statistically significant difference in participants' responses depending on the country they come from. Participants in the largest number of cases $(98 \%)$, responded that the quality of food served in 'salash' is excellent and that they were very satisfied. Researching the term "food quality", certain authors conclude tourists are satisfied if all organoleptic properties of food are satisfied (Jovićević, Simin, 2021; Čavić et al., 2021), and in the case of 'salash' in Serbia, hospitable and helpful staff is adding to a sense of satisfaction.

Table 4. Pearson Chi-Square Test

\begin{tabular}{|l|l|l|l|}
\hline Attachment 1. & Value & df & Statistical significance $(\mathrm{p})$ \\
\hline Pearson Chi-Square Test Male & 11.044 & 7 & 0.137 \\
\hline
\end{tabular}

Source: Own calculations 
According to Okumus et al. (2007), the sensory experience seemed to be the primary determinant of satisfaction. Thus, several gangs that are served, and also the colors of dishes that are served on the plates, matching the ingredients and spices, the smell of the dish (table 9), as well as the psychological moment i.e. the impression that something is of better quality if there is more of it. By examining tables 3 and 9, it can be concluded that a total number of $98 \%$ of participants agreed that the quality in chards is at the top level.

Table 5. Opinion of the participants

\begin{tabular}{|c|c|c|c|c|c|c|}
\hline & \multicolumn{3}{|c|}{ Number of dishes } & \multirow{2}{*}{ Total } \\
\hline & & & Like & Dislike & Neither & \\
\hline \multirow{16}{*}{ Country of origin } & \multirow{2}{*}{ Serbia } & Count & 37 & 1 & 1 & 39 \\
\hline & & $\%$ of Total & $12,5 \%$ &, $3 \%$ &, $3 \%$ & $13,2 \%$ \\
\hline & \multirow{2}{*}{$\mathrm{B} \& \mathrm{H}$} & Count & 60 & 0 & 1 & 61 \\
\hline & & $\%$ of Total & $20,3 \%$ &, $0 \%$ & ,3\% & $20,7 \%$ \\
\hline & \multirow{2}{*}{ Croatia } & Count & 23 & 1 & 0 & 24 \\
\hline & & $\%$ of Total & $7,8 \%$ &, $3 \%$ &, $0 \%$ & $8,1 \%$ \\
\hline & \multirow{2}{*}{ Macedonia } & Count & 6 & 0 & 1 & 7 \\
\hline & & $\%$ of Total & $2,0 \%$ &, $0 \%$ &, $3 \%$ & $2,4 \%$ \\
\hline & \multirow{2}{*}{ Montenegro } & Count & 37 & 0 & 0 & 37 \\
\hline & & $\%$ of Total & $12,5 \%$ &, $0 \%$ &, $0 \%$ & $12,5 \%$ \\
\hline & \multirow{2}{*}{ Slovenia } & Count & 78 & 0 & 1 & 79 \\
\hline & & $\%$ of Total & $26,4 \%$ &, $0 \%$ & ,3\% & $26,8 \%$ \\
\hline & \multirow{2}{*}{ Greece } & Count & 25 & 0 & 0 & 25 \\
\hline & & $\%$ of Total & $8,5 \%$ &, $0 \%$ &, $0 \%$ & $8,5 \%$ \\
\hline & \multirow{2}{*}{ Hungary } & Count & 23 & 0 & 0 & 23 \\
\hline & & $\%$ of Total & $7,8 \%$ &, $0 \%$ &, $0 \%$ & $7,8 \%$ \\
\hline \multirow{2}{*}{\multicolumn{2}{|c|}{ Total }} & Count & 289 & 2 & 4 & 295 \\
\hline & & $\%$ of Total & $98,0 \%$ &, $7 \%$ & $1,4 \%$ & $100,0 \%$ \\
\hline
\end{tabular}

Source: Own calculations

Data in table 6 also show that there was no statistically significant difference in participants' responses depending on the country they come from $(p=18.695)$. The number of gangs which is served at 'salash' is at the pleasure of participants and they all agreed that they ate and drank very well at 'salash'. Certain researchers concluded that traditional food is something people love and always return to (Lončarić et al., 2021), and 'salash' itself is a place where traditional dishes are served. Primarily this also means a traditional way of serving food is respected, which means several gangs (small dishes), from appetizer to dessert.

Table 6. Pearson Chi-Square Test

\begin{tabular}{|l|l|l|l|}
\hline Attachment 1. & Value & df & Statistical significance $(\mathrm{p})$ \\
\hline Pearson Chi-Square Test Male & 18.695 & 14 & 0.177 \\
\hline
\end{tabular}

Source: Own calculations 
The way something is served, as well as the people who are serving food also influence the guest's perception and his wish to visit the destination again (Perić et al., 2020). According to Rozin and Rozin (1981), the standard of food service represents the "ID" of the restaurant, and of the destination itself. Analyzing data from table 7, we can conclude that the respondents support this statement.

Table 7. Opinion of the participants

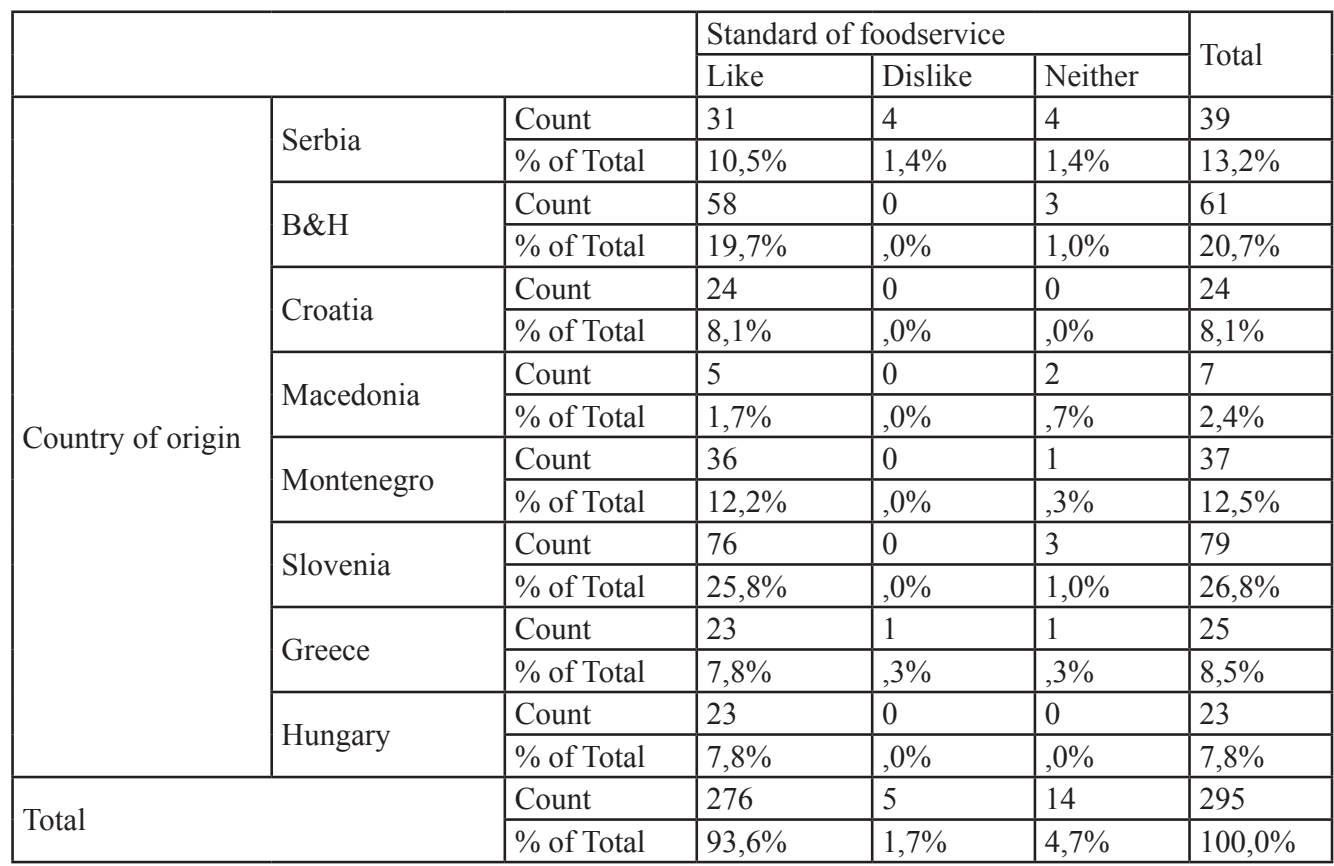

Source: Own calculations

Data in table 8 also show there was no statistically significant difference in participants' responses depending on the country they come from $(p=36.709)$.

Table 8. Pearson Chi-Square Test

\begin{tabular}{|l|l|l|l|}
\hline Attachment 1. & Value & df & Statistical significance (p) \\
\hline Pearson Chi-Square Test Male & 36.709 & 14 & 0.001 \\
\hline
\end{tabular}

Source: Own calculations

Data in table 9 show that almost $100 \%$ of tourists agreed that food and beverage which is served at 'salash' is diverse and abundant. According to authors Čavić et al., (2020), innovation and diversity of food present positive aspects of tourism development in a certain area, thus this piece of information is in correspondence with the stated facts. 
Table 9. Opinion of the participants

\begin{tabular}{|c|c|c|c|c|c|c|}
\hline & \multicolumn{3}{|c|}{ Variety of dishes } & \multirow{2}{*}{ Total } \\
\hline & & & Like & Dislike & Neither & \\
\hline \multirow{16}{*}{ Country of origin } & \multirow{2}{*}{ Serbia } & Count & 38 & 1 & 0 & 39 \\
\hline & & $\%$ of Total & $12,9 \%$ &, $3 \%$ &, $0 \%$ & $13,2 \%$ \\
\hline & \multirow{2}{*}{ B\&H } & Count & 60 & 0 & 1 & 61 \\
\hline & & $\%$ of Total & $20,3 \%$ &, $0 \%$ & ,3\% & $20,7 \%$ \\
\hline & \multirow{2}{*}{ Croatia } & Count & 24 & 0 & 0 & 24 \\
\hline & & $\%$ of Total & $8,1 \%$ &, $0 \%$ &, $0 \%$ & $8,1 \%$ \\
\hline & \multirow{2}{*}{ Macedonia } & Count & 7 & 0 & 0 & 7 \\
\hline & & $\%$ of Total & $2,4 \%$ &, $0 \%$ &, $0 \%$ & $2,4 \%$ \\
\hline & \multirow{2}{*}{ Montenegro } & Count & 37 & 0 & 0 & 37 \\
\hline & & $\%$ of Total & $12,5 \%$ &, $0 \%$ &, $0 \%$ & $12,5 \%$ \\
\hline & \multirow{2}{*}{ Slovenia } & Count & 79 & 0 & 0 & 79 \\
\hline & & $\%$ of Total & $26,8 \%$ &, $0 \%$ &, $0 \%$ & $26,8 \%$ \\
\hline & \multirow{2}{*}{ Greece } & Count & 25 & 0 & 0 & 25 \\
\hline & & $\%$ of Total & $8,5 \%$ &, $0 \%$ &, $0 \%$ & $8,5 \%$ \\
\hline & \multirow{2}{*}{ Hungary } & Count & 23 & 0 & 0 & 23 \\
\hline & & $\%$ of Total & $7,8 \%$ &, $0 \%$ &, $0 \%$ & $7,8 \%$ \\
\hline \multirow{2}{*}{\multicolumn{2}{|c|}{ Total }} & Count & 293 & 1 & 1 & 295 \\
\hline & & $\%$ of Total & $99,3 \%$ & ,3\% &, $3 \%$ & $100,0 \%$ \\
\hline
\end{tabular}

Source: Own calculations

Table 10 shows that participants' responses depending on the country they come from, statistically do not defer $(\mathrm{p}=10.429)$, which is corresponding to the research conducted by Brankov et al., (2019), according to which the diversity itself is the key to duration, and thus is the quality.

Table 10 Pearson Chi-Square Test

\begin{tabular}{|l|l|l|l|}
\hline Attachment 1. & Value & df & Statistical significance (p) \\
\hline Pearson Chi-Square Test Male & 10.429 & 14 & 0.730 \\
\hline
\end{tabular}

Source: Own calculations

Food presentation refers to the arrangement of food on the plate in a way that fulfills all organoleptic properties. According to Björk and Kauppinen-Räisänen (2018), food was described as hedonism, and food tourism was a journey in search for taste stimulation which is more than a combination of smell, taste, which is beautiful to the eye and which is arranged and served properly. All this represents food presentation. By examining Table 11 it can be concluded that approximately a half of participants stated that food presentation in chards is done properly, while another half of participants had different statements, $18 \%$ voted for inadequate presentation and $27,5 \%$ were undecided. 
Table 11. Opinion of the participants

\begin{tabular}{|c|c|c|c|c|c|c|}
\hline & \multicolumn{3}{|c|}{ Food presentation } & \multirow{2}{*}{ Total } \\
\hline & & & Like & Dislike & Neither & \\
\hline \multirow{16}{*}{ Country of origin } & \multirow{2}{*}{ Serbia } & Count & 19 & 6 & 14 & 39 \\
\hline & & $\%$ of Total & $6,4 \%$ & $2,0 \%$ & $4,7 \%$ & $13,2 \%$ \\
\hline & \multirow{2}{*}{$\mathrm{B} \& \mathrm{H}$} & Count & 43 & 11 & 7 & 61 \\
\hline & & $\%$ of Total & $14,6 \%$ & $3,7 \%$ & $2,4 \%$ & $20,7 \%$ \\
\hline & \multirow{2}{*}{ Croatia } & Count & 12 & 4 & 8 & 24 \\
\hline & & $\%$ of Total & $4,1 \%$ & $1,4 \%$ & $2,7 \%$ & $8,1 \%$ \\
\hline & \multirow{2}{*}{ Macedonia } & Count & 2 & 4 & 1 & 7 \\
\hline & & $\%$ of Total &, $7 \%$ & $1,4 \%$ &, $3 \%$ & $2,4 \%$ \\
\hline & \multirow{2}{*}{ Montenegro } & Count & 28 & 2 & 7 & 37 \\
\hline & & $\%$ of Total & $9,5 \%$ &, $7 \%$ & $2,4 \%$ & $12,5 \%$ \\
\hline & \multirow{2}{*}{ Slovenia } & Count & 32 & 19 & 28 & 79 \\
\hline & & $\%$ of Total & $10,8 \%$ & $6,4 \%$ & $9,5 \%$ & $26,8 \%$ \\
\hline & \multirow{2}{*}{ Greece } & Count & 14 & 5 & 6 & 25 \\
\hline & & $\%$ of Total & $4,7 \%$ & $1,7 \%$ & $2,0 \%$ & $8,5 \%$ \\
\hline & \multirow{2}{*}{ Hungary } & Count & 11 & 2 & 10 & 23 \\
\hline & & $\%$ of Total & $3,7 \%$ & ,7\% & $3,4 \%$ & $7,8 \%$ \\
\hline \multirow{2}{*}{\multicolumn{2}{|c|}{ Total }} & Count & 161 & 53 & 81 & 295 \\
\hline & & $\%$ of Total & $54,6 \%$ & $18,0 \%$ & $27,5 \%$ & $100,0 \%$ \\
\hline
\end{tabular}

Source: Own calculations

Authors Marković et al., (2019) showed in their research that an excellent presentation is a competitive advantage itself, and by analyzing table 12 we conclude that there is no statistically significant difference in participants' responses depending on the country they come from $(p=34.810)$.

Table 12. Pearson Chi-Square Test

\begin{tabular}{|l|l|l|l|}
\hline Attachment 1. & Value & df & Statistical significance (p) \\
\hline Pearson Chi-Square Test Male & 34.810 & 14 & 0.002 \\
\hline
\end{tabular}

Source: Own calculations

One may say that the traditional meal experience is recognized as the main part of the national cultural heritage and 0also the ethnic identity of their people. By getting to know the food of a population, we get to know its habits and way of life. Food is the identitiy of the destination. According to some researchers, these characteristics represent a contractual zone of attracting tourists to a destination, and a powerful reason for the transformation of rural areas (Carvache-Franco et al., 2021). Looking at Table 13 , we can conclude that the participants agree with the statement that food is a way to experience a traditional experience. 
Table 13. Opinion of the participants

\begin{tabular}{|c|c|c|c|c|c|c|}
\hline & \multicolumn{3}{|c|}{ Overall traditional meal experience } & \multirow{2}{*}{ Total } \\
\hline & & & Like & Dislike & Neither & \\
\hline \multirow{16}{*}{ Country of origin? } & \multirow{2}{*}{ Serbia } & Count & 38 & 0 & 1 & 39 \\
\hline & & $\%$ of Total & $12,9 \%$ &, $0 \%$ &, $3 \%$ & $13,2 \%$ \\
\hline & \multirow{2}{*}{$\mathrm{B} \& \mathrm{H}$} & Count & 60 & 1 & 0 & 61 \\
\hline & & $\%$ of Total & $20,3 \%$ &, $3 \%$ &, $0 \%$ & $20,7 \%$ \\
\hline & \multirow{2}{*}{ Croatia } & Count & 24 & 0 & 0 & 24 \\
\hline & & $\%$ of Total & $8,1 \%$ &, $0 \%$ &, $0 \%$ & $8,1 \%$ \\
\hline & \multirow{2}{*}{ Macedonia } & Count & 7 & 0 & 0 & 7 \\
\hline & & $\%$ of Total & $2,4 \%$ &, $0 \%$ &, $0 \%$ & $2,4 \%$ \\
\hline & \multirow{2}{*}{ Montenegro } & Count & 37 & 0 & 0 & 37 \\
\hline & & $\%$ of Total & $12,5 \%$ &, $0 \%$ &, $0 \%$ & $12,5 \%$ \\
\hline & \multirow{2}{*}{ Slovenia } & Count & 79 & 0 & 0 & 79 \\
\hline & & $\%$ of Total & $26,8 \%$ &, $0 \%$ &, $0 \%$ & $26,8 \%$ \\
\hline & \multirow{2}{*}{ Greece } & Count & 25 & 0 & 0 & 25 \\
\hline & & $\%$ of Total & $8,5 \%$ &, $0 \%$ &, $0 \%$ & $8,5 \%$ \\
\hline & \multirow{2}{*}{ Hungary } & Count & 23 & 0 & 0 & 23 \\
\hline & & $\%$ of Total & $7,8 \%$ &, $0 \%$ &, $0 \%$ & $7,8 \%$ \\
\hline \multirow{2}{*}{\multicolumn{2}{|c|}{ Total }} & Count & 293 & 1 & 1 & 295 \\
\hline & & $\%$ of Total & $99,3 \%$ &, $3 \%$ & ,3\% & $100,0 \%$ \\
\hline
\end{tabular}

Source: Own calculations

Authors Mladenović and Bojičić (2018), showed in their work that people love traditional products and that they easily bond with certain brands which are the synonyms of quality, and by analyzing table 13, we conclude that participants in 99 , $3 \%$ of cases agreed that 'salash' offers the unique, traditional experience, so there is no statistically significant difference here in participants' responses $(p=10.429)$ depending on the country they come from.

Table 14. Pearson Chi-Square Test

\begin{tabular}{|l|l|l|l|}
\hline Attachment 1. & Value & df & Statistical significance $(\mathrm{p})$ \\
\hline Pearson Chi-Square Test Male & 10.429 & 14 & 0.730 \\
\hline
\end{tabular}

Source: Own calculations

By analyzing tables 3, 5, 7, 9, and 15, we can conclude that the majority of tourists positively assessed the quality of service and food in the previously mentioned chardas and that this influences a positive attitude about the development of gastronomic tourism. Furthermore, this proves the hypothesis h4-the food and service in the restaurants represent the product which becomes the basis of tourist loyalty. 
Table 15. Opinion of the participants

\begin{tabular}{|c|c|c|c|c|c|c|}
\hline & \multicolumn{3}{|c|}{ Speed of service } & \multirow{2}{*}{ Total } \\
\hline & & & Like & Dislike & Neither & \\
\hline \multirow{16}{*}{ Country of origin } & \multirow{2}{*}{ Serbia } & Count & 8 & 20 & 11 & 39 \\
\hline & & $\%$ of Total & $2,7 \%$ & $6,8 \%$ & $3,7 \%$ & $13,2 \%$ \\
\hline & \multirow{2}{*}{$\mathrm{B} \& \mathrm{H}$} & Count & 13 & 27 & 21 & 61 \\
\hline & & $\%$ of Total & $4,4 \%$ & $9,2 \%$ & $7,1 \%$ & $20,7 \%$ \\
\hline & \multirow{2}{*}{ Croatia } & Count & 12 & 11 & 1 & 24 \\
\hline & & $\%$ of Total & $4,1 \%$ & $3,7 \%$ &, $3 \%$ & $8,1 \%$ \\
\hline & \multirow{2}{*}{ Macedonia } & Count & 1 & 5 & 1 & 7 \\
\hline & & $\%$ of Total &, $3 \%$ & $1,7 \%$ &, $3 \%$ & $2,4 \%$ \\
\hline & \multirow{2}{*}{ Montenegro } & Count & 25 & 8 & 4 & 37 \\
\hline & & $\%$ of Total & $8,5 \%$ & $2,7 \%$ & $1,4 \%$ & $12,5 \%$ \\
\hline & \multirow{2}{*}{ Slovenia } & Count & 42 & 21 & 16 & 79 \\
\hline & & $\%$ of Total & $14,2 \%$ & $7,1 \%$ & $5,4 \%$ & $26,8 \%$ \\
\hline & \multirow{2}{*}{ Greece } & Count & 8 & 14 & 3 & 25 \\
\hline & & $\%$ of Total & $2,7 \%$ & $4,7 \%$ & $1,0 \%$ & $8,5 \%$ \\
\hline & \multirow{2}{*}{ Hungary } & Count & 6 & 11 & 6 & 23 \\
\hline & & $\%$ of Total & $2,0 \%$ & $3,7 \%$ & $2,0 \%$ & $7,8 \%$ \\
\hline \multirow{2}{*}{\multicolumn{2}{|c|}{ Total }} & Count & 115 & 117 & 63 & 295 \\
\hline & & $\%$ of Total & $39,0 \%$ & $39,7 \%$ & $21,4 \%$ & $100,0 \%$ \\
\hline
\end{tabular}

Source: Own calculations

Table 16 does not show a statistically significant difference concerning participants' responses, since here is $\mathrm{p}=47.902$

Table 16. Pearson Chi-Square Test

\begin{tabular}{|l|l|l|l|}
\hline Attachment 1. & Value & df & Statistical significance (p) \\
\hline Pearson Chi-Square Test Male & 47.902 & 14 & 0.000 \\
\hline
\end{tabular}

Source: Own calculations

It is stated for gastronomy that it might be the main reason a tourist chooses a destination (Santich, 2004), as well as the reason to stay longer at a certain destination (Kivela and Crotts, 2006). For Mak et al. (2012a) the destination is an attraction for restaurants. 
Table 17. Opinion of the participants

\begin{tabular}{|c|c|c|c|c|c|}
\hline & \multicolumn{2}{|c|}{ Attractiveness of surroundings } & \multirow{2}{*}{ Total } \\
\hline & & & Like & Neither & \\
\hline \multirow{16}{*}{ Country of origin? } & \multirow{2}{*}{ Serbia } & Count & 35 & 4 & 39 \\
\hline & & $\%$ of Total & $11,9 \%$ & $1,4 \%$ & $13,2 \%$ \\
\hline & \multirow{2}{*}{$\mathrm{B} \& \mathrm{H}$} & Count & 60 & 1 & 61 \\
\hline & & $\%$ of Total & $20,3 \%$ &, $3 \%$ & $20,7 \%$ \\
\hline & \multirow{2}{*}{ Croatia } & Count & 24 & 0 & 24 \\
\hline & & $\%$ of Total & $8,1 \%$ &, $0 \%$ & $8,1 \%$ \\
\hline & \multirow{2}{*}{ Macedonia } & Count & 7 & 0 & 7 \\
\hline & & $\%$ of Total & $2,4 \%$ &, $0 \%$ & $2,4 \%$ \\
\hline & \multirow{2}{*}{ Montenegro } & Count & 36 & 1 & 37 \\
\hline & & $\%$ of Total & $12,2 \%$ &, $3 \%$ & $12,5 \%$ \\
\hline & \multirow{2}{*}{ Slovenia } & Count & 77 & 2 & 79 \\
\hline & & $\%$ of Total & $26,1 \%$ &, $7 \%$ & $26,8 \%$ \\
\hline & \multirow{2}{*}{ Greece } & Count & 21 & 4 & 25 \\
\hline & & $\%$ of Total & $7,1 \%$ & $1,4 \%$ & $8,5 \%$ \\
\hline & \multirow{2}{*}{ Hungary } & Count & 23 & 0 & 23 \\
\hline & & $\%$ of Total & $7,8 \%$ &, $0 \%$ & $7,8 \%$ \\
\hline \multirow{2}{*}{\multicolumn{2}{|c|}{ Total }} & Count & 283 & 12 & 295 \\
\hline & & $\%$ of Total & $95,9 \%$ & $4,1 \%$ & $100,0 \%$ \\
\hline
\end{tabular}

Source: Own calculations

Data from table 18 are similar to previous responses, so there is no statistically significant difference in participants' responses depending on the country they come from $(\mathrm{p}=16.815)$.

Table 18. Pearson Chi-Square Test

\begin{tabular}{|l|l|l|l|}
\hline Attachment 1. & Value & df & Statistical significance (p) \\
\hline Pearson Chi-Square Test Male & 16.815 & 7 & 0.019 \\
\hline
\end{tabular}

Source: Own calculations

Analyzing tables 13 and 17, we can conclude that the majority of tourists positively assessed the influence of the surroundings and the experience we get. This proves hypothesis h3-the environment that surrounds the Apatin chardas (national restaurants) is attractive and improves the overall impression $(\mathrm{t} \mathrm{13,17).}$

Based on the valorization, it is possible to notice that from all the chardas, only the Zlatna Kruna (Golden Crown) has the best grade for artistic value, thanks to the previously mentioned excellent parameters. Immediately after this charda, the Harčaš (Harchash) charda stands out. This charda has a special significance because of the beautifully landscaped environment in an attractive location near the Danube. After the Harchash Charda, the Kupusinksa Charda stands out for its specificity, it is ideal for all those who want to enjoy the silence and beauty of nature, and also who have the opportunity to spend the night, prepare food on their own, and drink coffee made in the old way. 
Table 19. SWOT

\begin{tabular}{|c|c|}
\hline STRENGTHS & WEAKNESSES \\
\hline $\begin{array}{l}\text { - } \text { Favorable geographic location } \\
\text { - Good connection with surrounding places } \\
\text { - } \text { Aulticulturalism } \\
\text { - } \text { tourism } \\
\text { - Treat gastronomic offer } \\
\text { - The existence of a tradition in the culture of } \\
\text { - The long tradition of the event } \\
\text { The Danube river }\end{array}$ & $\begin{array}{l}\text { - Poor infrastructure } \\
\text { - Poor tourist markings and road signs } \\
\text { - Insufficient cognizance } \\
\text { - Lack of information } \\
\text { - Lack of investment in tourism } \\
\text { - Lack of additional tourist attractions } \\
\text { - Lack of production and supply of souvenirs }\end{array}$ \\
\hline $\begin{array}{c}\text { OPPORTUNITIES } \\
\end{array}$ & THREATS \\
\hline $\begin{array}{l}\text { - Promotion of new ways of tourism } \\
\text { - Designing a new tourist offer } \\
\text { - Improving marketing activities } \\
\text { - Vacation segmentation into often and } \\
\text { shorter stays at the new destination (another } \\
\text { vacation) } \\
\text { - Internet access } \\
\text { - Local household interest for starting tourism }\end{array}$ & $\begin{array}{l}\text { - Lack of investment in gastronomic tourism } \\
\text { - Economic crisis } \\
\text { - High unemployment rate and the emigration } \\
\text { of the young and educated } \\
\text { - Lack of funding sources for infrastructure } \\
\text { and transport } \\
\text { - The fast growth of competition } \\
\text { - Losing position because of the competition }\end{array}$ \\
\hline
\end{tabular}

Source: Own calculations

Grades for the assessment of the gastronomy of the Apatin Chardas in tourism development, both with SWOT analysis (Table 19) and with valorization (Table 20) were:

VISION - At the very beginning of the development of this type of tourism, it is first necessary to determine the tour that tourists will make. This tour should contain a series of activities that will make time spent in Apatin beautiful and fulfilling to tourists. As people today more often decide on several brief vacations during the year, this weekend tour should attract tourists to visit the chardas as well as to improve the image of the destination itself. The tour would start from the charda "Zlatna kruna" (Golden Crown), where tourists would walk along the banks of the Danube and visit the Cathedral of the Holy Apostles, after which they would return to "Zlatna kruna" where hosts would offer them a fish stew and a roes pie.

After an afternoon meal and enjoyment along the banks of the Danube, tourists would choose whether to go by kayak with an instructor, for those who like to row alone, or by boat, for those who still prefer to feel the warm breeze on their faces. There they would be welcomed with an apéritif by their choice while listening to relaxing music of a good old tambourine. Here, tourists could enjoy some additional activities before dinner, such as cycling or, for fish lovers, fishing on the banks of the Danube and swimming in the river and for the youngest: games on the sand, skipping rope, badminton, playing marbles and other.

After enjoying additional activities, tourists could enjoy fish specialties for dinner, such as grilled fish, stuffed smoked carp; here tourists would spend the night under the starry sky in their tents to feel the true charm of nature. In the morning after breakfast, tourists 
would go to the last charda - Kupusinska charda, by boat or bicycle for those who love cycling, where they would all take part in preparing fish stew, so to bring with them and pass on to new generations the famous Apatin recipe.

After the meal, a fishing competition would be organized for both the older and younger population, after which prizes would be given for the first three places that tourists will take themselves as a souvenir, and for the first place the prize would be a tour of the Upper Danube special nature reserve. It would encourage revisiting the destination and enabling the development of other types of tourism. Also, the reward for children would be sweets in their weight. After laughter and fun, tourists would return by boat to the original chard where their journey begins and ends.

MISSION - The mission of this form of tourism is primarily to expand the business of chardas and establish cooperation with all relevant entities of economic and social life that are important for strengthening tourism in the Municipality of Apatin, as well as for the planning of its positioning in the market. It is necessary to enable the connection of key stakeholders who will work together to form and implement this tourist product. It is necessary to enable the branding of this area as attractive for tourists and to provide support, through regular and project activities. Furthermore, it is necessary to establish constant information and marketing support, publish printed issues and create a website. The most important is the cooperation with the Tourist Organization of the city of Apatin, which will actively present this form of tourism as well as directly raise interest in tourists towards gastronomic tourism.

AIM- The primary goal of this form of tourism is to establish cooperation with the local population so that residents gain insight into the importance of this form of tourism. Through this form of tourism, it is possible to develop the local community and raise the standard of living. Furthermore, it would enable the creation of a recognizable image of the destination as well as attract a larger number of tourists, both domestic and foreign. The development of this type of gastronomic tourism will contribute to preserving the tradition and emphasize the potentials that this city has. It is very important to fulfill all the expectations of tourists, to fulfill their wishes and requirements, to create a positive image of this type of tourism, to influence the extension of tourists' stay and their return. It is necessary to introduce modern trends in the field of marketing and communication to become visible and recognizable in the market. Some of the other goals are also the infrastructural development of the destination and the ultimate goal is to ensure the long-term competitive advantage of the destination in the market.

Table 20. Valorization according to quantitative-qualitative methodology

\begin{tabular}{|l|l|l|l|l|l|l|}
\hline & $\begin{array}{l}\text { Resource } \\
\text { accessibility }\end{array}$ & $\begin{array}{l}\text { Tourist } \\
\text { equipment }\end{array}$ & Surroundings & $\begin{array}{l}\text { Resource } \\
\text { specificity }\end{array}$ & $\begin{array}{l}\text { Resource } \\
\text { significance }\end{array}$ & $\begin{array}{l}\text { Artistic } \\
\text { value }\end{array}$ \\
\hline Chard "Zlatna Kruna" & 5 & 4.5 & 4.5 & 4 & 4.5 & 5 \\
\hline "Harčaš" Chard & 4 & 4.5 & 5 & 5 & 4.5 & 4.5 \\
\hline "Kupusinska" chard & 3 & 2.5 & 4 & 3.5 & 4 & 4 \\
\hline
\end{tabular}

Source: Own calculations 


\section{Conclusion}

The gastronomic offer of chardas represents a great potential for further development of tourism in the territory of the Municipality of Apatin. By developing this type of tourism, Apatin, as a tourist destination on the market, could offer a new product and attract new tourists. It is important to plan, in advance and with great care, the development of this type of tourism, to get the maximum benefit for all participants, as well as the tourists themselves. The development of this type of tourism would greatly contribute to the creation of the brand and recognition of Apatin as a tourist destination. Having all this in mind, we can conclude that the main hypothesis of the paper is proved.

Food is directly or indirectly related to Apatin, as a tourist destination; according to some authors, food encourages tourists to taste, and thus experience the local cuisine. In this paper, the lower level hypothesis h1 proved to be correct, just like the lower level hypothesis h4. For something to prove to be of high quality and thus have loyal consumers, it must, additionally, provide a certain satisfaction. This is exactly the triad of factors that affect loyalty: quality, satisfaction, loyalty.

Food and beverage are a powerful means of branding a country and means of its promotion. The involvement of food in tourism marketing and management has increased significantly in the last few decades. In some destinations, food is used as an eye-catcher in brochures, recordings, and television programs. In addition, the presentation of food takes place not only on the plates but also in the chardas. Apatin chardas have many gastronomic specialties that would lead to an increase in the number of guests (consumers) in this district, not only the production and preparation of dried meat products, pork scratching, soup, cooked meat, and tomato sauce but also the preparation and presentation of strudels, floating islands, and Bundt cakes. All this confirmed two hypotheses, $\mathrm{h} 2$ and $\mathrm{h} 3$.

\section{Conflict of interests}

The authors declare no conflict of interest.

\section{References}

1. Bošković, V. (2013): Hotel and restaurant offer on the territory of the municipalities of Apatin and Sombor (doctoral thesis), Department of Geography, Tourism and Hotel Management, Novi Sad (in Serbian)

2. Brankov, T., Markopoulos, T., Kontakos, S. (2019): Long-term trends in food consumption: comparison between Serbia and Greece, Economics of agriculture, 66(4), 941-953 doi:10.5937/ekoPolj1904975B

3. Björk, P., Kauppinen-Räisänen, H. (2018): Destination foodscape: A stage for travelers' food experience, Tourism Management, 71, 466-475

4. Charters, S., Pettigrew, S. (2005): Is wine consumption an aesthetic experience? Journal of Wine Research, 16(2), 121-136. 
5. Carvache-Franco, M., Orden-Mejía, M., Carvache-Franco, O., Carvache-Franco, W., Zambrano-Conforme, D. (2021): Attributes of the service that influence and predict satisfaction in typical gastronomy, International Journal of Gastronomy and Food Science (in the press- Article 100356)

6. Čavić, D., Radojković, M., Vujanović, M. (2020): Innovative food products as a basis for the development of rural tourism in Vojvodina, Economics of agriculture, 67(4), 1283-1295 doi:10.5937/ekoPolj2004283C

7. Čavić, S., Mandarić, M., Sekulić, D. (2021): Gastronomic events in the function of creating a brand of a tourist destination: the example of strudel festival in Dolovo, Economics of Agriculture, 68(3), 659-674 doi:10.5937/ekoPolj2103659C

8. Ćopić, M. (2016): Possibilities of using the banks of the Danube for the development of tourism in the municipality of Apatin, (doctoral thesis). Department of Geography, Tourism and Hotel Management, Novi Sad (in Serbian)

9. Günther, C. (2021): Carl Menger's different concepts of the value of money the enigma of "the inner value of money", Research in the History of Economic Thought \& Methodology, 39b, 23-42

10. Hall, C. M., Mitchell, R., (2001): Wine and gastronomy tourism, in Special Interest Tourism: Context and Cases, Douglas. N., Derret, R. (eds), John Wiley \& Sons: Brisbane, 307-329.

11. Hjalager, A., Richards, G., (2002): Tourism and Gastronomy. Routledge, London.

12. Petrović, M., Blešić, I., Vujko, A., Gajić, T. (2017): The role of agritourism impact on the local community in a transitional society: a report from Serbia, Transylvanian Review of Administrative Sciences, 50/2017, 146-163

13. Jovićević Simin, M., Živkucin, S. (2021): Application of the agricultural and food products trademark serving to increase the agricultural sector competitiveness, Economics of Agriculture, 68(3), 645-658 doi:10.5937/ekoPolj2103645J

14. Kivela, J., Crotts, J. C. (2006): Tourism and Gastronomy: Gastronomy’s influence on how tourists experience a destination, Journal of Hospitality\&Tourism Research, 30(3), 354-377

15. Lončarić, R., Sudarić, T., Zmaić, K. (2021): Traditional food products vs. Global economy: a consumer perspective, Economics of agriculture, 68(2), 389-405 doi. org/10.5937/ekoPolj2102389L

16. Mora, D., Solano-Sánchez, M., Lopez-Guzman, T., Moral-Cuadra, S. (2021): Gastronomic experiences as a key element in the development of a tourist destination, International Journal of Gastronomy and Food Science, 2021 Volume 25 (Cover date: October 2021) Article 100405

17. Marković, M., Krstić, B., Rađenović, Ž. (2019): Export competitiveness of the Serbian agri-food sector on the EU market, Economics of agriculture, 66(4), 941953 doi:10.5937/ekoPolj1904941M 
18. Mak, A. H. N., Lumbers, M., Eves, A., \& Chang, R. C. Y. (2012a): Factors influencing tourist food consumption, International Journal of Hospitality Management, 31(3), 928-936

19. Mak, A. H. N., Lumbers, M., \& Eves, A. (2012b). Globalization and food consumption in tourism, Annals of Tourism Research, 39 (1), 171-196

20. Mladenović, M., Bojičić, R. (2018): Production of Šar cheese - development opportunity for Štrpce municipality, Economics of agriculture, 65(3), 919-942 doi: 10.5937/ekoPolj1803929M

21. Okumus, B., Okumus, F., McKercher, B. (2007): Incorporating local and international cuisines in the marketing of tourism Destinations: The cases of Hong Kong and Turkey, Tourism Management, 28(1), 253-261

22. Perić, G., Dramićanin, S., Gašić, M. (2020): Impact of service quality on satisfaction and loyalty of tourists in rural tourism of Šumadija and Western Serbia, Economics of agriculture, 67(4), 1071-1086 doi:10.5937/ekoPolj2004071P

23. Radujko, D. (2008): Rural tourism in the municipality of Apatin, (doctoral thesis), Department of Geography, Tourism and Hotel Management, Novi Sad (in Serbian)

24. Rudić-Vranić, J. (1960): Fishing areas in Apatin, (book), Department of Geography, Tourism and Hotel Management, Novi Sad (in Serbian)

25. Rozin, E., Rozin, P. (1981): Culinary themes and variations, Natural History, 90, 6-14

26. Santich, B. (2004): The study of gastronomy and its relevance to hospitality education and training, International Journal of Hospitality Management, 23, $15-$ 24

27. Tadić, Lj. (2018): Opportunities for the development of tourism in the rural settlements of the municipality of Apatin, (doctoral thesis), Department of Geography, Tourism and Hotel Management, Novi Sad (in Serbian)

28. Vujko, A., Delić-Jović, M., Zečević, S.O., Zečević, L., Nedeljković, D. (2020): Gastronomy as a mean of marketing management and rural destination development, Serbian Journal of Engineering Management, 5(1), 1-13

29. Vuković, D., Vujko, A., Maiti, M., Riad, S.. (2019): Residents' perceptions of wine tourism on the rural destination's development, British Food Journal, 122(8), 2739-2753

30. Wolf, E. (2006): Gastronomy tourism: The Hidden Harvest. Kendall/Hunt Publishing, Dubuque. 